\title{
Strategic management: A perspective on the development of the field of strategic management and the contribution of the Irish Journal of Management
}

Research Article

Patrick Gibbons ${ }^{1 *}$, Pamela Sharkey Scott², Cormac Mac Fhionnlaoich

${ }^{1}$ Smurfit School of Business, University College Dublin,

Co. Dublin, Ireland

${ }^{2}$ School of Business, Maynooth University,

Maynooth, Co. Kildare, Ireland

\begin{abstract}
This paper analyses the progress made in the field of strategic management over the past three decades. One approach to analysing a discipline's trajectory is to explore its exemplary research. We review the papers awarded the Dan and Mary Lou Schendel, Strategic Management Society (SMS) Best Paper Award of the Strategic Management Journal (SMJ) since 1993, to demonstrate the emergence of strategic management as a specific discipline with a distinct view of how firms generate competitive advantage. Our paper interprets the development of the discipline from its market-based and structural roots to attempts to decipher the 'black box' of the organisation in analysing capabilities, particularly dynamic capabilities, and resources. Our study shows how the conceptual breakthroughs of the exemplary papers are further developed by the field through theory testing and extension using increasingly sophisticated methodologies published by journals such as Irish Journal Of Management (IJM). Our review of both journals highlights that despite increasing market, social and cultural instability since these seminal papers were first conceived, their lessons are still relevant and increasingly critical to both theory and practice in establishing the future trajectory for strategic management and a framework for organisations to compete.
\end{abstract}

Keywords: strategy $\bullet$ structure $\bullet$ resource base view

(C) De Gruyter Open Sp. z 0.0.

\section{Introduction}

It is extremely timely that the Irish Journal of Management (IJM), in seeking a series of retrospectives on the development of the field of management, should request a review of the strategic management field. In many ways, the histories of the journal and the field of strategy, as we know it, have evolved from similar birthdates. The forerunner of the IJM, IBAR, (Irish Business and Administrative Research) was first published in 1979, whilst two years earlier a conference was held at the University of Pittsburgh with the purpose of delineating a research agenda for the field of strategy. Both initiatives were about providing a forum and showcase for academic work that was previously relatively obscure.

The results and proceedings of the Pittsburgh conference were published in the seminal book, Strategic Management: A New View of Business Policy (Schendel and Hofer, 1980). This book served as a foundation document for research in the field, clearly demarcating a transition point between a view of strategy as serving primarily a teaching purpose, with faculty in the area delivering capstone courses such as Business Policy, to a research field with its own unique research questions, methods and agenda (Nag et al., 2007). Simultaneously, the other great impetus to the strategy field was the publication of Michael Porter's (1980) book, Competitive Strategy, which crystallised the insights developed through a long tradition of industrial organisation economics into 
frameworks for industry analysis, competitive intelligence and firm positioning. These foundations have produced very significant outcomes and by many measures, the field of strategic management has blossomed, boasting the second largest membership amongst interest groups in the Academy of Management (Hitt et al., 2004). Given this base, it is also the interest group with the largest number of submissions to the Annual Academy of Management Conference. The discipline's prime journal, Strategic Management Journal, (launched in 1980) has established itself as one of the premier journals in the management field (Wiseman and Skilton, 1999).

From the beginning, Schendel and Hofer (1980) were conscious of establishing a paradigm framing a basic research programme for strategy, to ensure scientific progress and legitimise strategic management in the broader field of management research. Research needed to capture '....a new concept of the general manager's role and responsibilities is developing, a concept we shall call strategic management' (p. 1). ${ }^{1}$ The major components of the research programme were to 'place entrepreneurial choice at the centre of the managerial universe...' (p. 6), and supplementing that with the primary concepts of strategic management as encompassing six major tasks, (1) goal formation, (2) environmental analysis, (3) strategy formulation, (4) strategy evaluation, (5) strategy implementation and (6) strategy control. In addition to facilitating communication and accumulation of findings, establishing a paradigm for strategic management would help to organise the research processes within the field and a period of normal science, characterised by broad consensus on major questions and approaches, would follow.

This paper reviews the development of the field since those early days, but does so in the light of assessing how 'normal science' within the strategic management paradigm has developed since the foundations were laid by Schendel and Hofer. Reflecting the simultaneous history of the IJM (and IBAR) and its facilitation of the dissemination of strategy research, this paper also reviews the development trajectory of strategy research published in the IJM over the past 30 years. We further consider the degree of integration between the themes and categories addressed in IJM and those addressed by the pre-eminent SMS award winning papers published in SMJ over this broadly overlapping timeframe. Our study shows how the conceptual breakthroughs of the exemplary papers are further developed by the field through theory testing and extension using increasingly sophisticated methodologies published by journals such as IJM.

\section{Literature review}

Prior reviews of the history of strategy considered the contribution of major books Bowman, Singh and Thomas (2002) or identified the methodological challenges that need to be addressed (Hitt et al., 2004). Ramos-Rodriguez and RuizNavarro (2004), in a very extensive bibliometric analysis, identified the major intellectual developments of the field, notably the key influences of specific books and the importance of award-winning papers (18 of the 20 most cited works in 1980-2000 were books). Specifically, they highlighted the profound influences of Porter's works (1980; 1985), Rumelt's work (1974) and the evolution of the resource-based view. Their finding of the importance of books in the development of the field masks the genetic importance of economics and organisation theory in the formation of the field. Five of the top 20 works can be readily associated with economists, namely, Williamson (1975; 1985), Nelson and Winter (1982), Cyert and March (1963) and Scherer (1980). Three of the works are readily identified with organisation theorists, Pfeffer and Salancik (1978), Thompson (1967) and Lawrence and Lorsch (1967). The remaining books are more clearly associated with writers in the strategic management tradition, Chandler (1962), Miles and Snow (1978), Hofer and Schendel (1978), Andrews (1971), Penrose (1959), Ansoff (1965) and Quinn (1980).

Nerur, Rasheed and Natarajan (2008) adopted a different approach to analysing the development of the field, focusing on the impact of specific authors. Their analysis confirmed the influence of Porter (1980, 1985), Williamson $(1975,1985)$, Pfeffer and Salancik (1978) and Mintzberg and Waters (1985). In addition, they identified intellectual communities in strategy as financial and institutional economics, industrial organization economics, strategy process researchers and power/resource dependence researchers. Furrer, Thomas and Goussevskaia (2008) analysis of 26 years of strategy research uncovered four basic orientations or 'poles' underlying the field: corporatelevel strategy, competitive strategies, the managers' strategic role and strategy as 'fit'. They found that the field's focus had shifted away from strategy process and environmental fit perspectives to corporate-level, competitivelevel and resource/capability perspectives. However, this review departs from these approaches to focus on how the 'paradigm' of strategic management, which was the essential project of the community of scholars who gathered

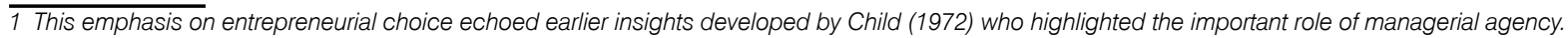


at the University of Pittsburgh in the late 1970s, has developed over the past 20 years by analysing the trajectory of the discipline's exemplar papers.

\section{Paradigm development and research programmes}

Paradigms capture a consensus view of the major research questions in a field of study, agreement on the appropriate theoretical lenses and primary methodological approaches to apply to problems. A paradigm increases the efficiency of research and helps to advance theory by providing a framework for communication and aggregation of findings (Pfeffer, 1993). The paradigm provides guidance to practitioners in the discipline by showing them examples of how their 'job' is to be done. This guidance and the identification of exemplars reflects some, usually consensual view, of examples of exemplars of the discipline. This paper argues that the 'best papers'2 as identified in the Strategic Management Journal (SMJ) serve as key signal to scholars in the field of strategy as to the importance of research questions, theoretical structures, methodological approaches and rhetorical styles.

We selected exemplary papers from SMJ for a number of reasons. First, the journal emerged as the 'new paradigm' of strategy was developed and served as a forum to address what the founding editorial board saw as four important themes (Schendel et al., 1980): (1) the development of corporate capability, including strategic leadership and other organisational variables; (2) a concern with the environment strategy-capability relationship, manifesting a concern with the 'fit' arguments that were then developing; (3) a focus on the strategic change process and (4) a concern with power relationships within and across organisations. Second, the journal is the journal of the Strategic Management Society, which is the dedicated learned society for strategic management scholars. Finally, the journal has developed as a premier journal and the journal is dominant in its field (Phelan et al., 2002; Ramos-Rodriguez and Ruiz-Navarro, 2004). In addition, other reviews, described earlier in this paper, have highlighted the contributions made by related fields such as economics and organisation theory to the development of the field, but by focussing on the best papers in SMJ, a more direct evaluation can be made about exemplary scholarship in the field. The emerging paradigm of strategic management emerging from this assessment is then utilised as a framework for demonstrating the contribution of the IJM to both theory and practice of strategy over the 30-year period.

\section{The exemplary studies}

Since 1993, the Strategic Management Journal has identified the best paper over the preceding five years or more. We selected and reviewed each of these papers and tried to identify the themes that the papers represent, their conceptual and methodological approaches and their major conclusions. Over the period, a total of 20 papers received the award. The vast majority of papers are focused on strategy formulation, so we developed a more fine-grained analytical scheme to classify the papers. This was done by the authors independently reviewing each paper and identifying the key themes featured in each paper. Six themes emerged from our analysis: strategy and structure; industry and firm effects; co-operative relationships; resource-based view; knowledge-based view and dynamic capabilities. As is evident, the latter three themes are focussed on the internal dynamics of the firm.

Having identified the six main themes from the SMJ best papers, an exploratory examination of the trajectory of strategy research published in the IJM over this same period was then compiled. More than 30 strategy-related papers were identified and categorised based on the themes highlighted in the SMJ best papers. (The papers are listed in Appendix 1). An application of the same categories serves to illuminate the relative theoretical foundations and methodology between the two sets of papers and identifies the role of IMJ in developing the conceptual themes brought forward in the exemplary SMJ papers.

\section{Theme 1, strategy and structure.}

The three award winning studies linking strategy and structure as summarised in Table 1 emphasise management's role in determining the strategic direction of the firm. Mintzberg and Waters (1985) focused on how strategic decisions are made and how the process influences the organisation's ability to learn and adapt to environmental conditions. The Miller (1986) paper adopts a broader perspective and considers not just the content of strategy but how this can be matched with particular organisational structures under different environmental conditions to provide generic configurations. This reduces complex conditions and inter-relating elements to the simplified structure of grids and

2 The Strategic Management Journal Best Paper prize was renamed 'The Dan and Mary Lou Schendel Best Paper Prize' in 2007 to recognise the many contributions made by the Schendels to Strategic management Journal, the Strategic Management Society and the community of scholars interested in strategy. 
is reminiscent of a more sophisticated multi-dimensional BCG matrix, but it provides an interesting framework for management to reconsider assumptions and applies more innovative approaches to how they align organisational strategy, structure and responding to environmental demands.

Table 1. Theme 1 , Strategy and Structure

\begin{tabular}{|c|c|c|c|}
\hline Author & $\begin{array}{l}\text { Methodology/ } \\
\text { Approach }\end{array}$ & Position on Strategy & Key Argument/Conceptualisations \\
\hline $\begin{array}{l}\text { Mintzberg and Waters (1985), } \\
\text { Of strategies, deliberate and } \\
\text { emergent, } 6: 3 \text { pp. } 257-272 \text {. } \\
\text { Year of award: } 2005\end{array}$ & $\begin{array}{l}\text { Conceptual. } \\
\text { Illustrative } \\
\text { examples cited. }\end{array}$ & $\begin{array}{l}\text { Explores how organisations } \\
\text { form strategies, criticising } \\
\text { the definition of strategy as a } \\
\text { 'pattern in a stream of decisions'. } \\
\text { Investigates the complexities of } \\
\text { strategy to define major features } \\
\text { of a typology. }\end{array}$ & $\begin{array}{l}\text { Argument on planned and incremental strategies } \\
\text { is perceived from the perspective of direction } \\
\text { and control. Strategies are conceptualised as a } \\
\text { continuum with deliberate strategies (requiring } \\
\text { precise information, collective intentions and } \\
\text { predictable environments) and pure emergent } \\
\text { strategies (implies absence of intention) as } \\
\text { extremes. Proposes typology of strategies along } \\
\text { the continuum include planned, entrepreneurial, } \\
\text { ideological, umbrella, process, unconnected, } \\
\text { consensus and imposed. }\end{array}$ \\
\hline $\begin{array}{l}\text { Miller (1986), Configurations } \\
\text { of strategy and structure, } \\
\text { Towards a Synthesis, pp. } \\
\text { 233-249. } \\
\text { Year of award: } 1995\end{array}$ & Conceptual & $\begin{array}{l}\text { Addresses strategy content and } \\
\text { how it relates to organisational } \\
\text { structure, proposing that for } \\
\text { any particular strategy there are } \\
\text { only a limited number of suitable } \\
\text { structures and vice versa. }\end{array}$ & $\begin{array}{l}\text { Particular 'gestalts' or generic configurations } \\
\text { of organisational forms are suited to specific } \\
\text { organisational strategies. Organisational features } \\
\text { are inter-related in complex and integral ways, and } \\
\text { their attributes are complementary and mutually } \\
\text { reinforcing. The strategic types defined by Miles } \\
\text { and Snow (1978) are matched with strategy } \\
\text { content to present five configurations. }\end{array}$ \\
\hline $\begin{array}{l}\text { Prahalad and Bettis (1986), } \\
\text { The Dominant Logic: A New } \\
\text { Linkage } \\
\text { between Diversity and } \\
\text { Performance, 7, pp. 485-501. }\end{array}$ & Conceptual & $\begin{array}{l}\text { Provides another perspective } \\
\text { on the 'relatedness' concept in } \\
\text { diversification research. }\end{array}$ & $\begin{array}{l}\text { Develops the concept of a 'dominant logic' } \\
\text { or a mental mindmap that develops from } \\
\text { management's experience in their core business. } \\
\text { An organisation's dominant logic is 'stored as } \\
\text { a shared cognitive map among the dominant } \\
\text { coalition' (pp. 491). Management's dominant logic } \\
\text { determines how they approach other businesses. } \\
\text { The performance of diversified firms then depends } \\
\text { on the appropriateness of the dominant logic to } \\
\text { cope with the strategic variety of its businesses. }\end{array}$ \\
\hline $\begin{array}{l}\text { Williamson (1991), } \\
\text { Strategizing, Economizing, } \\
\text { and Economic Organisation, } \\
\text { pp. 75-94. }\end{array}$ & $\begin{array}{l}\text { Conceptual, } \\
\text { illustrative examples } \\
\text { and deeper } \\
\text { description of a } \\
\text { case. }\end{array}$ & $\begin{array}{l}\text { Proposes that the transaction } \\
\text { cost economics (TCE) } \\
\text { fundamental to strategizing, as } \\
\text { economy is the best strategy for } \\
\text { firms to take. }\end{array}$ & $\begin{array}{l}\text { Argues for the principal efficiency approaches to } \\
\text { strategy and application of TCE to the governance } \\
\text { of the firm's contractual relations. Sees strategy } \\
\text { as relating to a limited number of management } \\
\text { decisions, and TCE and efficiency is the basis } \\
\text { of decision making. Strategy must begin with } \\
\text { economising. Highlights that the resource base } \\
\text { view and dynamic capabilities provide general } \\
\text { frameworks but that general structure is needed. }\end{array}$ \\
\hline
\end{tabular}

The Mintzberg and Waters (1985) paper conceptualises strategy development as a continuum, with the deliberate pole emphasising control and direction, whilst the other extreme represents flexibility and organisational adaptation to the environment. Adopting a strongly managerial perspective, the paper warns that the process of articulating a plan reduces adaptability and encourages adherence to a particular trajectory. Their proposed typology stresses the role of vision, adaptability and organisational ideology in strategy formation and the need to guard against formalisation of strategic planning as organisational size increases. Perhaps as a reaction to strategic management's previous fixation with grids and solutions, control is negatively presented, whilst management is urged to create a behavioural context that allows strategy to emerge. Overall, the paper concludes that management's approach must depend on the organisation's business environment; their emphasis must shift from control to flexibility and learning, so that 'strategy formation walks on two feet, one deliberate, the other emergent' (Mintzberg and Waters, 1985, p. 271).

The Miller (1986) paper adopts a wider brief and is seminal in its exploration of how strategy content relates to organisational structure. It argues for the existence of 'gestalts', capturing how organisational features are mutually reinforcing and inter-related (e.g. Miller [1986] suggested that large organisations incorporating standardisation, formal communications and tight control suit stable environments and supported cost leadership strategies, resulting in a cohesive configuration). Five strategy/structure configurations that embrace both strategy content 
and environmental conditions are developed. Whilst the taxonomies can be criticised for their oversimplification of complex realities, the paper provides an initial framework for both practitioners and academics to consider not just the appropriateness of a particular strategy's content to its organisational structure but the wider environmental influences that determine success. The limited number of award winning papers in this category, despite its fundamental nature in terms of what strategy is, how it is developed and its relationship with organisational structure, needs urgent revisiting to reflect and capture the evolution of theory within the discipline.

The Prahalad and Bettis paper (1986) provides an interesting indication (at least with the benefit of hindsight) of an emerging acknowledgement of the importance of management and management's conceptual abilities in the direction of the organisation. They propose that understanding the complexities of diversification must go beyond regressing economic and accounting variables and understanding management's 'dominant logic', defined by Prahalad and Bettis (1986, p. 490) as 'the way in which managers [in a firm] conceptualise the business and make critical resource allocation decisions'. This logic is stored in the manager's schemas or mindsets so that their belief structures and experiences to date influence, often unconsciously, their decision making. This perspective provides an alternative angle to researchers to conceptualise relatedness in the firm's portfolio of businesses. This paper evidences the emerging emphasis on the role of management and management decision making and its impact on firm performance within strategic management.

It is interesting that the most recent award to one of the oldest papers, Williamson (1991), strongly promotes the relevance of transaction cost economics (TCE) to management decision making. The key message of the paper is that whilst strategy plays a critical role in defeating rivals and competitive positioning, economic viability is the foundation of firm performance.

IJM contributions to Theme 1, Strategy and Structure: Reflecting the dominance of the debate within the field Strategy and Structure is by far the most sustained theme observed within the IJM, comprising almost $50 \%$ of all strategy papers published in this period. The papers demonstrate a particular focus on organisational structure. For example, Davey et al. (2010) considered the relationship between organisational structure and the management of innovation. Similarly, Ryan et al. (2007) viewed strategic repositioning as a conscious adaptation to a changing environment. In a contribution using a sample of Australian small-scale businesses, Griggs (2002) focused on the correlation between strategic planning and organisational effectiveness. Moroney (2000) viewed strategy development and evaluation as an integral part of the strategy process wherein the formality of the strategy evaluation process varies in accordance with the governing strategy process. Consistent with the SMJ papers in this theme, conceptual and case study approaches dominate.

\section{Theme 2, industry and firm effects}

This theme reflects strategic management's origins in industrial economics and manifests one of the primary ongoing research streams in the literature for explaining inter-firm variations in profitability. Papers are summarised in Table 2.

The Lieberman and Montgomery (1988) paper is notable in that whilst it examines a conceptual issue, how to discriminate between the effect of luck and skill on firm performance, it explores this in an unusual context, that of the first mover. Proctor and Gamble's launch of the disposable diaper coinciding with an unexpected baby boom colourfully illustrates their point. The paper is more pragmatic than the traditional economist's perspective, but the predominant approach is to find rules 'linking individual firm characteristics to optimal timing strategy ... what types of firms are best suited to pioneer' (Lieberman and Montgomery, 1988, p. 52), demonstrating a clear market perspective. The study recognises that management decides whether or not to pursue first mover opportunities arising through either organisational proficiency or simply through good luck!

The importance of what happens within the firm is further endorsed by Rumelt's (1991) support of heterogeneity within industries and also in its critical finding that business units within firms significantly differ and that little (2\%) of this difference is attributable to the corporation. As a result, Rumelt (1991) suggested that the business unit is the preferred unit of analysis in investigating variations in performance. The economist's argument that variations in business unit size can be attributed to differences in manufacturing efficiency are also refuted, as only a small portion of the large observed variance was due to differences in relative size. This paper reinforces the strategic management discipline's disenchantment with market analysis, providing tangible evidence of how little industry matters!

The Ocasio (1997) paper further exemplifies the transition within strategic management and its increasing recognition of the importance of investigating internal dynamics and processes within firms. Arguably, this paper could be categorised within the resource-based view (RBV), in that Ocasio (1997) developed a model of firm 
behaviour showing that the organisation's rules, resources and relationships influence the direction of the attention of key decision makers. However, as the key tenet of the Attention Based View is that what decision makers do depends on what issues they focus their attention on, which significantly impacts the firm's reaction and relationship with its environment (Ocasio, 1997), that is, the firm's strategic choices, the paper is categorised within this theme as it represents a further move from industry-based explanations of firm performance. The prominence of this paper exemplifies the shift in the attention of strategy researchers onto what happens within the firm for understanding organisational behaviour and adaptation.

Table 2. Theme 2, Industry and Firm Effects

\begin{tabular}{|c|c|c|c|}
\hline Author & $\begin{array}{l}\text { Methodology/ } \\
\text { Approach }\end{array}$ & Approach & $\begin{array}{l}\text { Key Argument/ } \\
\text { Conceptualisations }\end{array}$ \\
\hline $\begin{array}{l}\text { Lieberman, and Montgomery } \\
\text { (1988), First Mover } \\
\text { Advantages, Vol. 9, pp. 41-58. }\end{array}$ & Conceptual & $\begin{array}{l}\text { Proposes that first mover advantages are } \\
\text { derived from technological leadership, } \\
\text { pre-emption of assets and buyer switching } \\
\text { costs. First mover disadvantages } \\
\text { include free rider effects, resolution of } \\
\text { technological or market uncertainties, } \\
\text { shifts in technology or customer needs } \\
\text { and incumbent inertia. Definitional and } \\
\text { measurement issues include identification } \\
\text { of what constitutes a first mover, how to } \\
\text { measure first mover success and the size } \\
\text { and durability of advantage. }\end{array}$ & $\begin{array}{l}\text { Argues that luck or skill-based } \\
\text { asymmetries are the basis of achieving } \\
\text { super-normal profits, as evidenced by } \\
\text { the exploration of first mover advantage. } \\
\text { Particular conceptual problems apply } \\
\text { including how do you distinguish the } \\
\text { influence of proficiency from luck? Urges } \\
\text { organisations to consider their resource } \\
\text { base when pioneering, recognises the role } \\
\text { of management decision making when } \\
\text { deciding to pursue an opportunity arising } \\
\text { from either the organisation's skill or its } \\
\text { good fortune! }\end{array}$ \\
\hline $\begin{array}{l}\text { Rumelt (1991), How much } \\
\text { does industry mater, Vol. } 12 \text {, } \\
\text { pp. 167-185. } \\
\text { Year of award: } 1997\end{array}$ & $\begin{array}{l}\text { Examines the total } \\
\text { variance in rate of } \\
\text { return amongst } \\
\text { FTC Line of } \\
\text { Business units into } \\
\text { industry factors }\end{array}$ & $\begin{array}{l}\text { Empirical investigation of impact of } \\
\text { industry, time, corporate parent and } \\
\text { business-specific factors on business unit } \\
\text { performance. }\end{array}$ & $\begin{array}{l}\text { Disagrees with economic adoption of the } \\
\text { market as unit of analysis and argues that } \\
\text { industry effects are less than business unit } \\
\text { effects. Found that 'business units within } \\
\text { industries differ from one another more } \\
\text { than industries differ from one another' (pp. } \\
\text { 182). Industry membership can explain } \\
\text { only about } 8 \% \text { of the variation amongst } \\
\text { business unit performance. }\end{array}$ \\
\hline $\begin{array}{l}\text { Ocasio (1997), Towards an } \\
\text { Attention Based View of the } \\
\text { Firm } \\
\text { Vol. 18, Special Issue, pp. } \\
\text { 187-206 } \\
\text { Year of award: } 2011\end{array}$ & Conceptual & $\begin{array}{l}\text { Extending the seminal work of Herbert } \\
\text { Simon (1947) to develop propositions on } \\
\text { organisations as systems of distributed } \\
\text { attention. }\end{array}$ & $\begin{array}{l}\text { Provides an alternative explanation } \\
\text { to theories of firm behaviour based } \\
\text { on process-based views of strategy } \\
\text { formulation, firm behaviour and attention- } \\
\text { based dimensions. Develops a process- } \\
\text { based model of how firms behave based } \\
\text { on integrating theories of cognition, } \\
\text { organisational structure and strategy } \\
\text { formulation. }\end{array}$ \\
\hline
\end{tabular}

IJM contributions to Theme 2, Industry and Firm Effects: It is interesting to note that this area is not directly addressed by the IJM papers in our sample, possibly because of the perceived regional mission of the journal. The small absolute size of industries in the region and indeed the challenge of obtaining performance data on private firms competing in local industries may also contribute to the absence of studies on industry and firm effects within the journal. Alternatively, increased globalisation of industries and firms and Ireland's open economy may result in less attentiveness to regional concerns.

\section{Theme 3, co-operative relationships}

Whilst these two papers are the only award winning articles that look outside the firm to the organisation's broader relationships, the timing of their publication reflects strategic management's search for answers outside economics and the need for the discipline to provide alternative and independent theoretical frameworks addressing key management questions.

The Kogut (1988) paper is notable in that in addition to exploring a new business context, joint ventures (JVs) adopts multiple theoretical perspectives in its analysis. The paper uses a meta-analysis to consider the empirical support for each 'distinct' and 'overlapping' theory, and it is interesting to note that strategic behaviour theory is seen in the context of competitive positioning rather than building capabilities, which is classified as a noneconomic rationale for entering JVs. The Ring and van de Ven (1992) paper considers the importance of managing cooperative relationships not just from a transaction or hierarchical perspective but in terms of more social and behavioural aspects of trust and risk, a significant shift in contemporary thinking. 
Table 3. Theme 3, Co-operative Relationships

\begin{tabular}{|c|c|c|c|}
\hline Author & $\begin{array}{l}\text { Methodology/ } \\
\text { Approach }\end{array}$ & Approach & Key Argument/Conceptualisations \\
\hline $\begin{array}{l}\text { Kogut (1988), Joint } \\
\text { Ventures, Theoretical } \\
\text { and Empirical } \\
\text { Perspectives, Vol. 9, pp. } \\
\text { 319-332. }\end{array}$ & Meta-analysis & $\begin{array}{l}\text { Considers why firms engage in joint } \\
\text { ventures (JVs). The transaction cost } \\
\text { perspective sees JVs in terms of achieving } \\
\text { mutual hostage positions to reduce } \\
\text { uncertainty. Alternatively, the strategic } \\
\text { behaviour view predicts that JV partners } \\
\text { are selected to improve competitive } \\
\text { positioning. An alternative learning } \\
\text { perspective suggests that JVs are a means } \\
\text { by which firms seek new capabilities. }\end{array}$ & $\begin{array}{l}\text { Argues for multiple theoretical perspectives to } \\
\text { be adopted when exploring the rationale for } \\
\text { JVs. The transaction cost, strategic behaviour } \\
\text { and organisational learning perspectives are } \\
\text { considered and prior studies are analysed to } \\
\text { evaluate the empirical support for each view. The } \\
\text { paper also urges that the role of JVs in creating } \\
\text { oligopolies and national institutional structures } \\
\text { should also be considered. }\end{array}$ \\
\hline $\begin{array}{l}\text { Ring and van de Ven } \\
\text { (1992), Structuring Co- } \\
\text { operative relationships } \\
\text { between organisations, } \\
\text { Vol. 13(7), pp. 483-498. } \\
\text { Year of award: } 2008\end{array}$ & Conceptual & $\begin{array}{l}\text { Considers the alternative forms of } \\
\text { transactions - market-based discrete } \\
\text { contracts and hierarchies. Proposes that } \\
\text { governance structures are decided on } \\
\text { the basis of the risk and trust levels in a } \\
\text { transaction. A typology linking the risk of } \\
\text { the deal, with the reliance on trust between } \\
\text { the parties, to determine the governance } \\
\text { structure is developed. }\end{array}$ & $\begin{array}{l}\text { A broad perspective of markets, hierarchies and } \\
\text { recognition of the importance of relationships } \\
\text { underlie Ring and Van de Ven's (1992) conceptual } \\
\text { framework. The appropriate governance } \\
\text { structure for transactions based on the degree } \\
\text { of risk and the importance of trust between the } \\
\text { parties, comprise discrete, recurrent or relational } \\
\text { contracting and hierarchy. }\end{array}$ \\
\hline
\end{tabular}

IJM contributions to Theme 3, Co-operative Relationships: The recognition of new business contexts and relationships is also reflected in publications within the IJM. Both economic transactional and behavioural perspectives are used to explore key concepts. For example, Boyle (1993) considered the choice between markets and hierarchies through vertical integration, whilst Coughlan et al. (2002) explored process issues in addressing collaboration with suppliers. Organisational learning and execution skills in the management of mergers and acquisitions are considered by Gomes et al. (2007). The conceptual themes are explored through case studies and in-depth narratives, which permit a finer-grained examination of process and behaviour amongst smaller firms in regional economies.

\section{Theme 4, resource base view (RBV) papers}

The RBV selection of papers outlined in Table 4 reflects the emergence of strategic management as an independent discipline with an emerging portfolio of perspectives for addressing the 'black box' of firm heterogeneity.

The RBV represents the principal contribution of the strategic management discipline to the theory of why firms exist and to explain firm performance and strategic choice. Economists argue that firm's achieve competitive advantage by deterring market entry and increasing prices above long-run costs. In contrast, the RBV shifts attention to the firm and suggests that competitive advantage is achieved when idiosyncratic and difficult to replicate resources allow firms to offer better quality or reduce costs relative to their competitors. Wernerfelt's (1984) seminal paper evidences a critical transition for strategic management from its foundations in product-market-based perspective to examining how the internal resources of the firm, particularly its technology capabilities, influenced the strategic options available to management and ultimately to organisational performance. Even at the time, Wernerfelt (1984, p. 180) acknowledged that this paper was a 'first cut at a huge can of worms', an initial step in the monumental task of identifying the organisation's critical resources and how its capabilities could be combined across divisions.

The Leonard-Barton (1992) paper developed our understanding of what happens within the firm through exploring the contribution of core capabilities and their potential downside core rigidities. Leonard-Barton (1992) identified that the organisation's values and norms impact its core capabilities as they are infused within the other influential dimensions of the firm's technical systems, its skills and knowledge base and its managerial systems. Whilst innovation is enabled by an organisation's core competencies, when a gap emerges between emerging environmental requirements and the firm's core capabilities then a paradox may arise. The values, managerial and technical systems that triggered innovation are by then embedded in the organisation and may turn into core rigidities, which hamper future innovation. These capabilities are difficult to change as 'they include a pervasive dimension of values' (p. 123), but organisations must constantly and actively seek to redefine their core capabilities in dynamic environments.

The Peteraf (1993) paper represents a significant development of RBV theory as it integrates the then emerging consensus on the conditions necessary to achieve competitive advantage through organisational resources. Peteraf 
(1993) developed a model illustrating that difference in firm profitability cannot be explained by differences in industry conditions. Heterogeneity of firm resources, particularly knowledge-based resources or core competencies allow some firms to earn monopoly rents. Maintaining these rents requires that these resources are imperfect in terms of imitability, substitutability and mobility. Peteraf (1993) suggested that managers of single businesses should evaluate resources against the four criteria and identify those critical for sustainable advantage. From a corporate strategy perspective, assessing the transferability of a firm's resources will determine the appropriateness of the extent and type of its diversification strategy. As argued by Peteraf (1993, p. 190), 'it is the only theory of corporate scope which is capable of explaining the range of diversification, in all its richness, from related constrained to the conglomerate form'. This notable paper represents the initial definition of the criteria for achieving competitive advantage through what happens within the firm, the first attempts to unpack the black box.

Table 4. Theme 4, Resource Base View Papers

\begin{tabular}{|c|c|c|c|}
\hline Author & $\begin{array}{l}\text { Methodology/ } \\
\text { Approach }\end{array}$ & $\begin{array}{l}\text { Approach to Resource- } \\
\text { Based View }\end{array}$ & Key Argument/Conceptualisations \\
\hline $\begin{array}{l}\text { Wernerfelt (1984), Resource } \\
\text { based view of the firm, , Vol. } 5 \text {, } \\
\text { pp. 171-180. }\end{array}$ & $\begin{array}{l}\text { Exploratory } \\
\text { Conceptual }\end{array}$ & $\begin{array}{l}\text { A firm's resources at a given time } \\
\text { could be defined as those (tangible } \\
\text { and intangible) assets, which are } \\
\text { tied semi-permanently to the firm. }\end{array}$ & $\begin{array}{l}\text { Ground-breaking examination of firms in terms } \\
\text { of resources (instead of products) to identify } \\
\text { their strategic options. } \\
\text { A firm can utilise its resources (e.g. customer } \\
\text { loyalty, technological leads) to create a }\end{array}$ \\
\hline Year of award: 1994 & & $\begin{array}{l}\text { Introduces/develops the ideas } \\
\text { of valuable and rare resources, } \\
\text { substitutability of resources and } \\
\text { capabilities as resources. }\end{array}$ & $\begin{array}{l}\text { situation where other firms must catch up with } \\
\text { it to compete. Firms need to build a resource } \\
\text { position barrier to protect their advantage in } \\
\text { product/markets, similar to entry barriers. Uses } \\
\text { Porter's } 5 \text { Forces model to analyse resources in } \\
\text { different market positions. }\end{array}$ \\
\hline $\begin{array}{l}\text { Leonard-Barton (1992), } \\
\text { Core Capabilities and Core } \\
\text { Rigidities: A paradox in } \\
\text { managing new product }\end{array}$ & Case Studies & $\begin{array}{l}\text { Examines the core capabilities that } \\
\text { underlie the RBV. Core Capability } \\
\text { defined as the knowledge set } \\
\text { that distinguishes and provides a }\end{array}$ & $\begin{array}{l}\text { In addition to the influence of technical systems, } \\
\text { skills and managerial systems, core capabilities } \\
\text { are deeply rooted in the organisation's values. } \\
\text { Core rigidities that inhibit innovation can arise. }\end{array}$ \\
\hline
\end{tabular}

development, Vol. 13, pp.

$111-125$. competitive advantage.

Year of award: 2001

Pereraf (1993), The

cornerstones of competitive

advantage: a resource based

view, Vol. 14, pp. 179-191.

Year of award: 1999

Amit and Schoemaker

(1993), Strategic Assets and

Organisational Rent, Vol. 14

pp. 33-46.

Year of award: 2000

Conceptual

An economic approach to the RBV

Conceptual

Henderson and Cockburn

(1994), Measuring

Competence? Exploring Firm

Effects in Pharmaceutical

Research

15(S1), pp. 63-84

Year of Award, 2010
Empirical paper incorporating both quantitative and qualitative approaches.
Marshalling a set of complementary and specialised resources and capabilities that are scarce, durable, not easily traded and difficult to imitate, may enable the firm to earn economic rents. Resources are stocks of available factors that are owned or controlled by the firm. Distinguishes between resources and capabilities (a firm's capacity to deploy resources), usually in combination, using organisational processes, to effect a desired end. They are information-based, tangible or intangible processes that are firm specific.

Distinguishes between two types of capability that may contribute to firm advantage, 'component' competence or local abilities related to routine problem solving and 'architectural' competence or the ability to integrate knowledge and develop new competences.
Identifies four conditions which underlie sustained competitive advantage; superior resources, ex post limits to competition, imperfect resource mobility and ex ante limits to competition.

Suggests how the model applies to both business and corporate strategy.

Adopting the firm as the unit of analysis, the paper identifies the desired characteristics of the firm's resources and capabilities. It combines Strategic Industry factors, or the critical determinant of industry profitability with strategic assets, referring to a particular firm's set of resources and capabilities, to identify conditions for creating competitive advantage.

Explores of firm effects by measuring the effects of organisational competence in the context of pharmaceutical research, confirms the importance of architectural competence in building advantage.

Methodological problems in measuring competences are identified, particularly in separating the impact of specific competences from other sources of unobserved organisational heterogeneity.

Importance of identifying the sources of

organisational competences and how

competence outcomes are impacted by how

they are managed. 
Amit and Schoemaker (1993) reintroduced the importance of the organisation's operating context by providing guidance on identifying the critical resources and capabilities for achieving profitability in an industry (Strategic Industry Factors) and then comparing these to the firm's resources and capabilities (its Strategic Assets). In addition, Amit and Schoemaker (1993) extended theory by introducing the dimension of management's decision making biases and organisational implementation aspects as influencing resource and capability transferability and imitability. The notable contribution of this paper is the notion that management decisions on resource and capability development are critical in determining a firm's ability to survive in a competitive market.

Henderson and Cockburn's (1994) empirical exploration of the impact of organisational competences in pharmaceutical research agencies identifies some of the critical problems in RBV theory testing, particularly the difficulty in isolating the impact of specific competencies on firm productivity. This is particularly critical as the RBV is now a mainstream theory of strategic management, and the decisions that management must make in terms of which resources and capabilities to develop have now become the critical issues rather than product or market considerations. Even the broader strategies such as business strategy and corporate strategy can now be evaluated based on the organisations resources and capabilities as well as positioning within industries. The Leonard-Barton paper (1992) introduces what has led to the major criticisms of the RBV, its lack of applicability to dynamic markets with the introduction of the idea of core rigidities. In addition, perhaps in response to frustration arising from how the economist and the consultants view the achievement of competitive advantage, the underlying theory of the RBV almost defies attempts to measure and classify the resources and capabilities, which it suggests represent the firm's ability to create competitive advantage. But whilst the economist view neglected what happened within the firm, the RBV can be criticised for treating the organisation's internal elements such as a black box, which magically differentiate firm performance. Even the RBV's distinction between resources and capabilities was initially vague, although this is at least partially addressed by the Peteraf (1993) paper. The emphasis on what happens within the firm also fails to link RBV and strategy content, formation and organisational structure. However, the RBV spawned interest in the inner workings and dynamics of the firm, a key platform of the strategic management paradigm.

IJM contributions to Theme 4, Resource Based View (RBV): The increasing dominance of the RBV, and particularly the focus on core capabilities highlighted by Amit and Schoemaker (1993) and Leonard-Barton (1992) is reflected within the IJM, One scholar argues for the role played by intangible resources in impacting firm performance (López, 2006; López and Iglesias, 2010), whilst others make the case for leveraging social capital (Weisingera and Black, 2006), and organisational culture (Kenny and Ready, 2006) in developing strategic resources.

In relation to methodology, the IJM illustrates how RBV theory is maturing from an early focus on theory development through case studies (Weisingera and Black, 2006) to a recent shift to theory testing and extension using sophisticated statistical techniques including principal component analysis (López, 2006) and structural equation modelling (López and Iglesias, 2010). Thus evidences the continuing dialogue within the discipline as path breaking conceptual developments within the exemplary papers are translated through theory testing and extension to become accepted frameworks for addressing critical management issues.

\section{Theme 5, knowledge-based view of the firm}

As illustrated by the analysis in Table 5, the papers addressing the knowledge-based view of the firm are almost like a separate and independent perspective to the RBV.

The Levinthal and March (1993) paper identifies the shift in strategic management's focus from planning and rational calculation for achieving profitability to the internal capabilities of the firm and the RBV but warns that achieving success requires balancing complex and often contradictory organisational demands. Levinthal and March (1993) notably extended the analysis of management's difficulties in decision making, particularly in allocating resources, identifying the restrictions of ignorance, conflicting preferences and ambiguity, which can lead to learning myopia. Their paper emphasises that there are no easy solutions for the internal black box, as, for example, focusing on exploitation of current successes increases resource commitment to match current environmental conditions endangers the organisation's exploration activities that underpin future growth, whilst emphasising exploration focuses on achieving future success and may neglect resource building from exploiting current successes. This paper provided the platform for the emergence of the knowledge-based view of the firm and a dedicated SMJ Special Issue from which the following three papers were selected for the best paper award.

The first of these papers by Spender (1996) argues that the firm is an organic structure and that words cannot capture the dimensions of its existence or facilitate a full understanding of its existence by even those within the organisation. He proposed that the knowledge-based view is a paradigm shift from perceiving the firm as an entity 
to establishing knowledge as a process as the unit of analysis, and the theory is a 'tool to help managers discover their place in the firm as a dynamic knowledge based activity system' (Spender, 1996, p. 45). His philosophical paper provides a valuable framework for the further development of the firm and is notable in that it departs from the strongly positivist perspective of the Strategic Management Journal to consider nuances and more blurred boundaries.

In contrast, Szulanski's (1996) empirical study adopts a pragmatic approach and suggests that problems with knowledge transfer within the organisation are due not to inappropriate incentives or the Not Invented Here syndrome as previously considered but to the context of the transfer and the characteristics of the knowledge transferred. The critical contribution of this paper, however, is not its empirical findings but that it poses the question of 'why organisations do not know what they know' (Szulanski, 1996, p. 38). The fundamental question of knowing what knowledge exists to be transferred precedes problems arising from knowledge transfer and prompts future exploration of facilitating mechanisms for increasing management's awareness of organisational knowledge.

Table 5. Theme 5, Knowledge-Based View of the Firm

\begin{tabular}{|c|c|c|}
\hline Author & Methodology & Approach \\
\hline $\begin{array}{l}\text { Levinthal and March (1993), } \\
\text { The Myopia of Learning, Vol. } \\
14 \text { (S2), pp. 95-112. } \\
\text { Year of award: } 2002\end{array}$ & Conceptual & $\begin{array}{l}\text { Learning defined as 'capabilities } \\
\text { for responding to experience by } \\
\text { modifying their technologies, forms } \\
\text { and practices' (pp. 96). Paper } \\
\text { explores how organisations are } \\
\text { both constrained and extended by } \\
\text { their ability to learn. Specialisation } \\
\text { and simplification are used by } \\
\text { organisations to facilitate learning } \\
\text { from experience. }\end{array}$ \\
\hline
\end{tabular}

Szulanski (1996), Vol. 17, pp. 27-43. Exploring internal stickiness: impediments to the transfer of best practice within the firm

Year of award: 2004

Grant (1996), Towards a knowledge based theory of the firm, Vol. 17, pp. 109-122.

Year of award: 2006
Empirical

Conceptual with illustrations

(1)

Major barriers to knowledge transfer are not perceived as motivational but because of recipient's lack of absorptive capacity, causal ambiguity effects on knowing what to transfer, and source/donor relationship conflicts. Identifies the transfer process stages as initiation of the transfer decision, progress the transfer decision, ramp-up and integration when the knowledge transferred becomes 'part of the recipient's system'.

Explores how organisations use integrating mechanisms to coordinate the specialist knowledge of their members. Identifies four integrating mechanisms; rules and directives, sequencing, routines and group problem solving and decision making, based on a shared common knowledge.

Conceptual

Spender (1996), Making knowledge the basis of a dynamic theory of the firm, Vol. 17, pp. 45-62

Year of award: 2006

\section{Key Argument/Conceptualisations}

Argues that organisations need to learn to survive but that learning also constrains opportunities for growth. Management's simplification of experiences to accommodate bounded rationality can lead to myopia and emphasis on short term results, narrower perspectives and overestimation of the transferability of current competencies. Learning traps make it challenging to balance exploration of new knowledge and exploitation of existing knowledge. Proposes that learning generally boosts firm profitability and reliability through routinisation.

Argues that difficulties in transferring best practices internally arise because of 'internal stickiness' of knowledge transfer. Prompts questions for broader knowledge management theory - particularly emphasising the dangers of firm not knowing what it knows so that a gap forms between what knowledge it could exploit and what it does exploit.

Argues that the rationale for firm existence is its role as an integrator, its unique approach to managing some activities, particularly knowledgerelated activities. Proposes that capabilities arise from the organisation's knowledge integration. Perceives the firm as a knowledge integrating institution implying less bureaucracy with individual playing multiple organisational roles and participating in multiple organisational teams. Knowledge integration also implies that decisions requiring tacit and idiosyncratic knowledge are decentralised. As a result, the paper argues that the organisation's primary problem is coordinating its activities.

Argues that competitive advantage arises from the firm's unique ability to add value to its input, its knowledge and its knowledge generation capacity. Views the dynamics of knowledge creation as implying disciplined interaction between implicit and explicit knowledge at both the individual and organisational level. Derives a complexactivity-based approach to knowledge-based theory, which embraces the evolutionary nature of human activity systems. Suggests four heuristics to guide management: interpretive flexibility (to how resources are used), boundary management (outsourcing, downsizing), identification of institutional influences (external factors) and distinguishing between systemic and component features (what is critical to your organisation). 
Grant's (1996, p. 100) study also differs in that it presents the knowledge-based view as not a theory of why firms exist but 'focuses on knowledge as the most strategically important of the firm's resources'. Whilst this paper emerges from the resource-based view, it differs by adopting the individual as the 'primary actor in knowledge creation and the principal repository of knowledge' (Grant, 1996, p. 142) within the organisation. This, in our view, is one of the papers that offers the most promise for future theory building, the need for co-ordination of individuallevel resources within the organisation. However, because of their specific focus on knowledge and knowledge management, this selection of papers does not develop the RBV as a general theory, as is evidenced by the emergence of the Dynamic Capabilities literature.

IJM contributions to Theme 5, Knowledge-Based View: Several papers published by the IJM build on the ideas proposed by the seminal papers. For example, Higgs (2006) viewed the knowledge-based view of the firm as an extension of the RBV, arguing that knowledge is the key productive resource of the firm. Similarly, reflecting the contributions of Spender (1996, 1998), Higgs (2006, p. 142) suggested that organisational learning seeks to understand the nature of knowledge and distinguishes between explicit knowledge and tacit knowledge arguing that the interaction between the two modes of knowledge is vital for the creation of new knowledge. Farrell et al. (2005) found that the learning capacity of the organisation is strongly impacted by the leadership characteristics, such that in their empirical study, they found that transformational leadership mediated by trust impacts the ability of the firm to integrate knowledge. This is consistent with the idea of the firm capacity to build capabilities is reliant on its capacity to engage in knowledge integration (Grant 1996). Here we perceive a strong and welcome integration between the seminal SMJ papers and the related IJM papers.

In relation to methodology, Higgs (2006) focused on conceptual development. Farrell et al. (2005) utilised factor analysis and regression analysis in their empirical study and found that trust mediates the relationship between transformational leadership and the firm's ability to integrate knowledge. As with the literature on the RBV, increasing methodological sophistication is applied to the study of theory and concepts developed in earlier literature.

\section{Theme 6, dynamic capabilities}

As illustrated by the analysis in Table 6, the Dynamic Capabilities literature both extends and deepens our knowledge of the RBV and, to some extent, is similar to the knowledge base view, developing as an independent theory of the firm. Perhaps most importantly, however, conceptual progress in this theme evidences how strategy has emerged as an independent discipline, focused on the 'messy aspects' inside the firm, rather than more clear cut economic rules.

The RBV is now a mainstream theory of explaining firm competitive advantage but it continues to be criticised for being tautological. The continuing disillusionment with economic and even RBV explanations of differentials in firm performance, how do some firms perform better than others with similar resources, led to the emergence of a new theoretical approach that explores how different organisational processes enabled firms to exploit their resources, particularly in rapidly changing environments, the dynamic capabilities (DC) perspective. Whilst the economic approach to strategy treats firms as 'black boxes', overlooking firm differences and focusing on their technological position, Nelson (1991) argued that how organisations differ in their ability to generate and exploit innovation depends on their dynamic capabilities, not on their command over a particular technology as economists suggests. Arguably, this paper could have been classified within the Strategy and Structure Theme earlier, as Nelson (1991) contrasts theories of the firm based on neo-classical economics with evolutionary views. In many ways, this paper animated the investigation of dynamic capability perspectives on firm heterogeneity. Thus, this paper emphasizes the importance of investigating internal dynamics and processes within firms as being as important as market position perspectives.

This recognition of capabilities as dynamic is pivotal in terms of strategic management's attempts to explain how firms differ in how they utilise their resources to create competitive advantage. Nelson (1991) argued that organisation must have coherent strategy that defines the boundaries of its activities and a supportive structure that builds DCs to position the firm to compete in the next round of technology-driven change through learning and innovating. Responses to environmental change will, Nelson (1991) suggested, require a change in capabilities and often in management. The paper exemplifies the transition within strategic management from a relatively static approach to explaining short-term differential performance to longer-term, sustained performance differences.

Teece, Pisano and Shuen (1997) extended Nelson's (1991) argument that DCs support the importance of strategy in explaining differences in firm performance. Teece et al. (1997, p. 515) theorised that DCs are complicated routines that emerge from path-dependent processes, 'appropriately adapting, integrating, and reconfiguring 
internal and external organizational skills, resources and functional competences to match the requirements of a changing environment'. DCs are firm specific, as they cannot be readily assembled in the market place but are built in the context of 'organisational structures and managerial process, which support productive activity' ( $p$. 517). These processes result from the embodiment of organisational learning within its routines and are reflected in the firm's technology, intellectual property, complementary assets and network of relationships. This supports their notion of path dependency as prior learning is embodied in the firms 'repertoire of routines' which is the foundation of future behaviour. Teece et al. (1997) proposed that competitors are similarly path dependent, so that organisational progress or what it may become is constrained by what it has been and the learning it has embodied in its processes.

Table 6. Theme 6, Dynamic Capabilities

\begin{tabular}{lll}
\hline Author & Methodology & Approach \\
\hline \hline $\begin{array}{l}\text { Nelson, 1991, Why do firms } \\
\text { differ, and how does it matter? }\end{array}$ & Conceptual & $\begin{array}{l}\text { Dynamic capabilities considered } \\
\text { in terms of lead capabilities such } \\
\text { Vol. 12, pp. } 61-74 .\end{array}$ \\
as R\&D in dynamic environments, \\
Year of award: 2009 & $\begin{array}{l}\text { embracing localised learning in a } \\
\text { dynamic context. }\end{array}$ \\
\end{tabular}

Teece, Pisano and Shuen (1997), Dynamic capabilities and strategic management, Vol. 18 (7), pp. 509-533.

Year of award: 2003

Eisenhardt and Martin, 2000, Dynamic Capabilities: What are they? Vol. 21, pp. 1105-1121.

Conceptual

Conceptua - Illustrative examples

Year of award: 2007
Dynamic capabilities defined as: The firm's ability to integrate, build and reconfigure internal and external competences to address rapidly changing environments.

Dynamic capabilities defined as: the firm's processes to integrate, reconfigure gain and release resources - to match and even create market change. Dynamic capabilities thus are the organisational and strategic routines by which firms achieve new resource configurations as markets emerge, collide, split, evolve and die.

Capabilities defined as:
A higher-level routine (or collection
of routines) that together with
its implementing input flows,
confers upon an organisation's
management a set of decision
options for producing significant
outputs of a particular type...
Dynamic capabilities govern the rate
of change of ordinary capabilities.
Key Argument/Conceptualisations

Economists recognise that firms differ but attribute differences to the firm's context, rather than to management discretion or decision making. . Need to progress from Economist's market view to looking inside the firm. Competition is not about costs, but about finding new ways of doing things. Firm differences are critical to economic progress. Dynamic capabilities not just an important guide to management, but the basis of an evolution theory of economic changes, providing instruction on why firms differ

Identifies processes, positions and paths as classes of factors that help determine a firm's distinctive competence and DCs. DCs enable competitive advantage: they are embedded in processes, but the context of these processes is shaped by the firm's position and its evolutionary path.

DCs a tool for manipulating resource configurations faster or better than competitors. Significant communalities in what constitutes a DC.

RBV focuses on leverage but long-term competitive advantage infrequently achieved in dynamic markets. It may be more realistic to focus on creating a series of temporary advantages by acting on opportunity. DCs evolve from learning mechanisms of repeated practice, codification of experience into technology and formal procedures, consolidation of learning and learning from mistakes.

Classification of DCs - lower order (making a living) and higher order (driving change in capabilities). Capabilities involve patterned activity to achieve specific objectives, but DCs may be more random and 'non-routine'. Can have change without DCs - ad hoc problem solving, a fire fighting approach in response to dramatic environmental chance. Firms should seek to achieve a balance between expensive DCs (a patterned approach to environmental change) and ad hoc problem solving to maintain organisational flexibility.

In contrast to the Teece et al.'s (1997) view, the Eisenhardt and Martin (2000, p. 1105) paper argues that DCs are a 'set of specific and identifiable processes', and as they can be replicated across all firms, their contribution to competitive advantage lies not in the DCs themselves but in the resource configurations they produce. As a result, DCs are necessary but not sufficient to achieve competitive advantage in dynamic markets. Eisenhardt and Martin (2000) adopted a pragmatic approach to analysing how dynamic capabilities build competitive advantage. They 
extended the argument by providing examples of organisational functions and routines that manipulate resources such as strategy development process but proposed that it is not the capabilities that build competitive advantage, but the emerging resource configurations that allow the organisation to build competitive advantage, 'to generate new value creating strategies' (p. 1107). Eisenhardt and Martin (2000) suggested that this interpretation addresses some of the criticisms that DCs are tautological and facilitates empirical analysis and identification of commonalities for building effective DCs. But there still remains an unexplained 'black box' in terms of how do you manipulate DC to provide the best resource configurations for generating competitive advantage. Suggesting that there is equifinality or multiple independent paths to developing the same DC does not provide significant practitioner guidance or an identifiable route for theory building. However, endorsing the view of Nelson (1991), Eisenhardt and Martin (2000) concluded that DCs are best conceptualised as tools that help to achieve sustained competitive advantage through determining winning resource configurations.

Winter's (2003) paper defends dynamic capabilities, arguing for their existence separate to zero-order capabilities that merely enable an organisation to 'make a living' in the short term. Organisational routines can be developed, which build higher-order DCs 'to extend, modify or create ordinary capabilities', which can be combined with ad hoc problem solving to drive organisational change. The essence of the difference is the routine approach, the 'patterning of the activity' that requires long-term commitments to specialised resources, which is costly to maintain so should be supported by ad hoc problem solving as required. Patterns may be driven by simple rules and structural principles as suggested by Eisenhardt and Martin (2000), others from practised performance building on a combination of micro-patterns. This paper notably warns that DCs are not a 'rule for riches' as competing firms are also not only building their own DCs but can also simultaneously adopt imitative strategies. Winter (2003) suggested that DCs do not provide simple rules for dealing with change and 'generic' formulas for achieving competitive advantage but may drive the recombination and resequencing of the organisation's resources in response to change.

The selected prize winning papers in this theme ask similar questions in terms of how organisations can convert capabilities into competitive advantage in response to dynamic markets. Each paper offers an 'organisational and empirical lens, rather than an economic and formal modelling one' to examine DCs, as processes embedded in firms. These exemplary papers demonstrate the emergence and clarification of the concept of DCs, as strategy researchers constantly strive to understand the 'black box' that differentiates firm performance. The need to look inside the firm is increasingly evident, as this determines how the organisation will respond to its external environment and how it configures its resources in response to that change. Whilst Teece et al. (1997) focused on the changes to the processes delivering competitive advantage, Eisenhardt and Martin (2000) suggested that it is the resource configurations that emerge from the organisation's response to environmental change. This configuration of resources is a function of the firm's higher-order capabilities for change (Winter, 2003), ad hoc problem solving (Winter, 2003) and the path that has brought the firm to that particular point (Teece et al., 2007). The papers are also unanimous in their caution that DCs do not provide a 'get rich quick' rule but are a 'helpful addition to the tool kit of strategic analysis, where strategic analysis itself remains a matter of understanding how the idiosyncratic attributes of the individual firm affects its prospects in a particular competitive context' (Winter, 2003, p. 995).

It appears that despite the best efforts of leading strategists and significant progress in definition, 'the processes through which particular resources provide competitive advantage remain in a black box' (Priem and Butler, 2001, p. 33).

IJM contributions to Theme 6, Dynamic Capabilities: Papers published by IJM add to the debate on dynamic capabilities and significantly contribute to both theory testing and theory development over the period, using a range of methodologies from case studies to sophisticated statistical approaches. O'Driscoll et al. (2001) emphasised the simultaneous building and leveraging of competencies through systems of innovation, market orientation, organisational development through learning and knowledge management and the case studies explored highlight how failure to consider each of these strands together may lead to a competence trap. Higgs (2006) identified the role of top management team processes and the impact of these processes on performance. Smith et al. (1996) using hierarchical regression highlighted the critical role of organisational processes in leveraging resources and capabilities to bring about improvements in team and organisational performance. More recently, Walsh et al. (2011) conceptually examined and schematically modelled the impact of the dynamic capability of firm-level innovativeness in the tourism industry. Their study demonstrated that whilst single innovations may be replicated by others, the process of innovativeness becomes a dynamic capability that is socially embedded in the organisation. Focusing on organisational processes has allowed for deeper examination of issues surrounding strategic implementation, illustrating the significant contribution of the IJM in testing and extending the seminal conceptual fabric of our discipline. 


\section{Conclusions and future directions}

Our study confirms the critical role of journals such as IJM in developing and testing the conceptual breakthroughs of the exemplary papers published in SMJ. The IJM plays an important part in extending and translating the highly conceptual approach evidenced in the award winning papers (of the 20 papers honoured, the vast majority are conceptual papers) to more specific theoretical and managerial guidance. In reviewing the themes identified in the SMS exemplary papers and categorising the strategy papers published in the IJM over the same period, we can be confident that the IJM papers are indeed reflective of similar themes and concerns expressed in the leading international literature. It is reassuring to find that the development of the themes follow a similar line of evolution, starting with a broad focus on strategy and structure moving to the themes of the resource-based view along with knowledge and dynamic capabilities. The increasing richness of the empirical work in IJM in relation to both regional data and more sophisticated methodology is to be commended. As far as conceptual discourse around the more recent themes of the RBV, knowledge and dynamic capabilities are concerned, the IJM studies reflect well in relation to their peer studies in SMS honoured papers.

The conceptual focus of the SMS award winning papers and similarly of many studies within the IJM is not surprising, given that strategy is a nascent field where theory is required to guide the research endeavour. Theoretical development is the font of empirical research and so it is not surprising that in a new field, theoretical development that animates and guides empirical work should be seen by practitioners in the field as exemplary. The trend in theory development towards looking internally in the firm is also quite obvious with papers reflecting the resource, knowledge and dynamic capabilities perspectives dominating the exemplary papers honoured in SMJ. This trend, whilst welcome in deepening our understanding of the sources of advantage, poses difficulties in theory testing because of the under-developed measures of many of the constructs developed in these perspectives. Developing these measures and identifying the critical constructs provide rich opportunities for journals such as IJM.

Further challenges relate to identifying the critical constructs for measurement in the new competitive landscape. Recently, Rumelt (2009) suggested that the current economic crisis raises questions about the fundamental approaches of strategy research, methods and major issues addressed by the field to date. As strategy is fundamentally about explaining sustained differences in firm performance over time, the most important dependent variable in the majority of strategy studies to date has been some dimension of performance, typically financial performance. But should shareholders interests continue to dominate strategy research? The recent crisis has highlighted the necessity of at least supplementing financial performance measures with other dimensions salient to other stakeholders, for example, the impact of economic activity on the environment.

The second indication that strategy research may be approaching a structural break identified by Rumelt (2009) relates to the limited number of studies incorporating risk explicitly as a key variable in both assessments of strategy and assessments of performance. In reviewing all of the exemplary papers that received awards, and the related IJM papers, little mention is made of risk. This is somewhat surprising as early research in the field emphasised risk assessment (Bettis and Thomas, 1990). Cross-sectional studies relating variations in performance to variations in 'strategy' or related variables are particularly suspect, without consideration of the risk appetites, biases, errors and decisions that have preceded the observations of data. Thus, of all fields, strategy requires longitudinal assessments of strategic moves and consequences. Moreover, organisational outcomes are a result of the myriad of discrete investment, and other resource commitment decisions made at various levels, and insight into the ways these decisions are formulated and implemented requires more fine-grained insight into decision making. Many of the studies published in journals such as IJM make valuable contributions to addressing this need, given their focus on small and medium enterprises in small economies, which offer a rich source of more fine-grained case study material.

In addition to the contribution of the IJM to the emerging conceptual frameworks, there may be other opportunities for providing both theoretical and managerially relevant insights. The small economy advantage of the IJM may well represent an opportunity for future specialisation building on characteristics of local market conditions. Ireland's heavy reliance on foreign direct investment provides opportunities for research addressing issues subsidiaries of multinational companies in regional economies (e.g. mandate extension, subsidiary initiative and capability development). The IJM does of course contribute to other important aspects of strategic management theory outside the scope of this paper. 
In conclusion, the field of strategy has progressed very significantly in just more than 30 years. Our study confirms that the conceptual breakthroughs of the exemplary papers are further developed by the field through theory testing and extension using increasingly sophisticated methodologies published by journals such as IJM. Further theoretical progress requires deeper empirical insight into the dynamics of strategy formulation and execution. This is particularly challenging as managers trained in the vernacular of strategy organise and reproduce their world using the strategy concepts propagated by business schools and consulting firms, and then researchers question managers about their world. The pervasiveness and extent of this double hermeneutic (Giddens, 1993) is a manifestation of the success of the strategy field. Looking back over the past 30 years has allowed us to identify where we have come from, the conceptual foundations of our discipline. Going forward will require new insights, new ideas and new inspirations. As they emerge, these new concepts and constructs will need to be translated, extended and tested by journals such as IJM, so that managers will have the artillery to respond to the challenges of developing and implementing strategy in an ever-changing business landscape.

\section{References}

Amit, R. and Schoemaker, P.H.J. (1993) Strategic Assets and Organizational Rent, Strategic Management Journal, 14(1), pp. 33-46.

Andrews, K. (1971) The Concept of Corporate Strategy, Homewood. III: Dow-Jones-Irwin.

Ansoff, H.I. (1965) Corporate Strategy, New York: McGraw Hill.

Bettis, R.A. and Thomas, H. (eds) (1990) Risk, Strategy, and Management, Greenwich, CT: JAI Press.

Bowman, E.H., Singh, H. and Thomas, H. (2002) 'The Domain of Strategic Management: History and Evolution', in A. Pettigrew, H. Thomas and R. Whittington (eds) Handbook of Strategy and Management, London: Sage Publications.

Boyle, E. (1993) Value-Adding Partnerships as Alternatives to Vertical Integration: An Exploratory Discussion by Reference to Some Northern Ireland Examples, Irish Journal of Business and Administrative Research, 14(2), p. 29.

Chandler, A.D. (1962) Strategy and Structure: Chapters in the History of Modern Industrial Enterprise, Cambridge Mass: MIT Press.

Child, J. (1972) Organizational Structure, Environment and Performance: The Role of Strategic Choice, Sociology, 6(1), pp. 1-22.

Coughlan, P., Coughlan, D., Brennan, L., Lombard, F., McNicols, T. and Nolan, R. (2002) Collaboration in High Technology Companies in Ireland: Three Case Studies, Irish Journal of Management, 23(1), pp. 19-29.

Cyert, R.M. and March, J.G. (1963) A Behavioral Theory of the Firm, Englewood Cliffs, NJ: Prentice Hall.

Davey, S.M., Brennan, M., Meenan, B.J. and McAdam, R. (2010) The Health of Innovation: Why Open Business Models Can Benefit the Healthcare Sector, Irish Journal of Management, 30(1), pp. 21-40.
Eisenhardt, K. M. and Martin, J. A. (2000) Dynamic Capabilities? Do They Matter?, Strategic Management Journal, 21(10), pp. 1105-1121.

Farrell, J.B., Flood, P.C., Mac Curtain, S., Hannigan, A., Dawson, J. and West, M. (2005) CEO Leadership, Top Team Trust and the Combination and Exchange of Information, Irish Journal of Management, 26(1), pp. 22-40.

Furrer, O., Thomas, H. and Goussevskaia, A. (2008) The Structure and Evolution of the Strategic Management Field: A Content Analysis of 26 Years of Strategic Management Research, International Journal of Management Reviews, 10(1), pp. 1-23.

Giddens, A. (1993) New Rules of Sociological Method, London: Polity Press.

Gomes, E., Donnelly, T., Morris, D. and Collis, C. (2007) Improving Merger Process Management Skills over Time: A Comparison of Acquisition Processes of Jaguar and of Land Rover by Ford, Irish Journal of Management, 28(1), pp. 31-40.

Grant, R. M. (1996) Toward a Knowledge-based Theory of the Firm, Strategic Management Journal, 17, pp. 109-122.

Griggs, H.E. (2002) Strategic Planning System Characteristics and Organisational Effectiveness in Australian Small-Scale Firms, Irish Journal of Management, 23(1), pp. 23-51.

Henderson, R. and Cockburn, I. (1994) Measuring Competence? Exploring Firm Effects in Pharmaceutical Research, Strategic Management Journal, 15(S1), pp. 63-84.

Higgs, M. (2006) What Makes for Top Team Success? A Study to Identify Factors Associated with Successful Performance of Top Management Teams, Irish Journal of Management, 27(2), pp. 161-188

Hitt, M.A., Boyd, B.K. and Li, D. (2004) 'The State of Strategic Management Research and a Vision 
for the Future', in D.J. Ketchen and D.D. Bergh (eds) Research Methodology in Strategy and Management, Volume 1, pp. 1-31, Amsterdam: Elsevier.

Hofer, C. and Schendel, D. (1978) Strategy Formulation: Analytical Concepts, West: St. Paul.

Kenny, B. and Reedy, E. (2006) The Impact of Organisational Culture Factors on Innovation Levels in SMEs: An Empirical Investigation, Irish Journal of Management, 27(2), pp. 119-142.

Kogut, B. (1988) Joint Ventures: Theoretical and Empirical Perspectives, Strategic Management Journal, 9(4), pp. 319-332.

Lawrence. P. and Lorsch, J. (1967) Organization and Environment: Managing Differentiation and Integration, Homewood, III: Irwin.

Leonard -Barton, D (1992) Core Capabilities and Core Rigidities: A Paradox in Managing New Product Development, Strategic Management Journal, 13(S1), pp. 111-125.

Levinthal, D. A. and March, J.G. (1993) The Myopia of Learning, Strategic Management Journal, 14(S2), pp. 95-112.

Lieberman, M. and Montgomery, D. B. (1988) Firstmover Advantages, Strategic Management Journal, 9(1), pp. 41-58.

López, V. (2006) An Alternative Methodology for Testing a Resource-Based View Linking Intangible Resources and Long-Term Performance, Irish Journal of Management, 27(2), pp. 49-66.

López, V.A. and Iglesias, S. (2010) A ReputationalPerformance Framework in an SME Context: Some Empirical Evidence from Spain, Irish Journal of Management, 29(2), pp. 35-66.

Mackenzie, K.D. and House, R. (1978) Paradigm Development in the Social Sciences: A Proposed Research Strategy, Academy of Management Review, 3, pp. 7-23.

Miles, R.E. and Snow, C. (1978) Organizational Strategy, Structure and Process, New York: McGraw Hill.

Miller, D. (1986) Configurations of Strategy and Structure: Towards a Synthesis, Strategic Management Journal, 7(3), pp. 233-249.

Mintzberg, H. and Waters, J.A. (1985) Of Strategies, Deliberate and Emergent, Strategic Management Journal, 6(3), pp. 257-272.

Moroney, M. (2000) Strategy Evaluation: Towards an Updated Paradigm, Journal of Irish and Business Administrative Research, 21(1), pp. 103-129.

Nag, R., Hambrick, D.C. and Chen, M.J. (2007) What Is Strategic Management Really? Inductive Derivation of a Consensus Definition of the Field, Strategic Management Journal, 28(9), pp. 935-955.
Nelson, R.R. (1991) Why Do Firms Differ, and How Does It Matter?, Strategic Management Journal, 12(S2), pp. 61-74.

Nelson, R.R. and Winter, S.G. (1982) An Evolutionary Theory of Economic Change, Cambridge, Mass: Harvard University Press.

Nerur, S.P., Rasheed, A. and Natarajan, V. (2008) The Intellectual Structure of the Strategic Management Field: An Author Co-Citation Analysis, Strategic Management Journal, 29(3), pp. 319-336.

Ocasio, W. (1997), Towards an Attention-based View of the Firm, Strategic Management Journal, 18(S1), pp. 187-206.

O'Driscoll, A., Carson, D. and Gilmore, A. (2001) The Competence Trap: Exploring Issues in Winning and Sustaining Core Competence, Irish Journal of Management, 22(1), pp. 73-90.

Peteraf, M.A. (1993), The Cornerstones of Competitive Advantage: A Resource-Based View, Strategic Management Journal, 14(3), pp. 179-191.

Penrose, E. (1959) The Theory of the Growth of the Firm, London: Basil Blackwell.

Pfeffer, J. (1993) Barriers to the Advance of Organizational Science: Paradigm Development as a Dependent Variable, Academy of Management Review, 18, pp. 599-620.

Pfeffer, J. and Salancik, G.R. (1978) The External Control of Organizations: A Resource Dependence Perspective, New York: Harper and Row.

Phelan, S., Ferreira, M. and Salvador, R. (2002) The First Twenty Years of the Strategic Management Journal, Strategic Management Journal, 23, pp. 1161-1168.

Porter, M.E. (1980) Competitive Strategy: Techniques for Analyzing Industries and Competitors, New York: The Free Press

Porter, M.E. (1985) Competitive Advantage, New York: The Free Press.

Prahalad, C. K and Bettis, R.A. (1986). The Dominant Logic: A New Linkage Between Diversity and Performance, Strategic Management Journal, 7(6), pp. 485-501.

Priem, R. L. and Butler, J.E. (2001) Is the ResourceBased 'View'a Useful Perspective for Strategic Management Reseach?, The Academy of Management Review, 26(1), pp. 22-40.

Quinn, J.B. (1980) Strategies for Change; Logical Incrementalism, Homewood III: Richard D. Irwin.

Ramos-Rodriguez, A.R. and Ruiz-Navarro, J. (2004) Changes in the Intellectual Structure of Strategic Management Research: A Bibliometric Study of the Strategic Management Journal, 1980-2000, Strategic Management Journal, 25(10), pp. 981-1004 
Ring, P.S. and van de Ven, A. H. (1992) Structuring Cooperative Relationships Between Organizations, Strategic Management Journal, 13(7), pp. 483-498.

Rumelt, R.P. (1974) Strategy, Structure and Economic Performance, Cambridge Mass: Harvard Business School Press.

Rumelt, R.P. (1991) How Much Does Industry Matter?, Strategic Management Journal, 12(3), pp. 167185.

Rumelt R.P. (2009) Strategy in a Structural Break, McKinsey Quarterly, pp. 35-42.

Ryan, P., Moroney, M., Geoghegan, W. and Cunningham, J. (2007) A Framework for a Strategic Repositioning Strategy: A Case Study of Bulmers Original Cider, Irish Journal of Management, 28(1), pp. 81-102.

Schendel, D. and Hofer, C. (eds) (1980) Strategic Management: A New View of Business Policy and Planning, Boston: Little Brown and Company.

Schendel, D., Ansoff, H.I. and Channon, D.C. (1980) Statement of Editorial Policy, Strategic Management Journal, 1, pp. 1-5.

Scherer, F.M. (1980) Industrial Market Structure and Economic Performance, Boston Mass: Houghton Mifflin.

Simon, H.A. (1947) Administrative Behavior: A Study of Decision-Making Processed in Administrative Organisations., New York: Macmillan.

Smith, K.G., Smith, K.A., Olian J.D. and Sims, H.P. (1996) Top Management Team Demography and Process: The Role of Social Integration and Communication, Irish Business and Administrative Research, 17(1), pp. 36-69.

Spender, J.-C. (1996) Making Knowledge the Basis of a Dynamic Theory of the Firm, Strategic Management Journal, 17, pp. 45-62.

Spender, J.-C. (1998) 'The Dynamics of Individual and Organisational Knowledge', in C. Eden and J. Spender (eds) (1998) Managerial and
Organisational Cognition: Theory, Methods and Research, London: Sage.

Szulanski, G. (1996) Exploring Internal Stickiness: Impediments to the Transfer of Best Practice Within the Firm, Strategic Management Journal, 17 , pp. 27-43.

Teece, D. J., Pisano, G. and Shuen, A. (1997) Dynamic Capabilities and Strategic Management, Strategic Management Journal, 18(7), pp. 509-533.

Thompson, J.D. (1967) Organizations in Action, New York: McGraw Hill.

Walsh, M., Lynch, P. and Harrington, D. (2011) A Capability-Based Framework for Tourism Innovativeness, Irish Journal of Management, 31(1), pp. 21-41.

Weisingera, J.Y. and Black, J.A. (2006) Strategic Resources and Social Capital, Irish Journal of Management, 27(1), pp. 145-170.

Wernerfelt, B. (1984) A Resource-based View of the Firm, Strategic Management Journal, 5(2), pp. 171-380.

Williamson, O.E. (1975) Markets and Hierarchies: Analysis and Antitrust Implications, New York: The Free Press.

Williamson, O.E. (1985) The Economic Institutions of Capitalism: Firms, Markets, Relational Contracting, I New York: The Free Press.

Williamson, O.E. (1991) Strategizing, Economizing, and Economic Organization, Strategic Management Journal, 12(2), pp. 75-94.

Winter, S.G. (2003) Understanding Dynamic Capabilities, Strategic Management Journal, 24(10), pp. 991995.

Wiseman, R.M. and Skilton, P.F. (1999) Divisions and Differences: Exploring Publication Preferences and Productivity Across Management Subfields, Journal of Management Inquiry, 8(3), pp. 299320. 


\section{Appendix 1}

\section{Irish Journal of Management: Strategy paper categorisation}

\section{Theme 1, Strategy and structure}

\begin{tabular}{|c|c|c|}
\hline Author & Methodology & Position on Strategy \\
\hline $\begin{array}{l}\text { Davey, S. M., Brennan, M., Meenan, B.J. and McAdam, R. } \\
\text { (2010), The Health of Innovation: Why Open Business Models } \\
\text { Can Benefit the Healthcare Sector, 30:1, pp. 21-40 }\end{array}$ & Qualitative/case studies & $\begin{array}{l}\text { Organisational structure facilitates the } \\
\text { management of innovation }\end{array}$ \\
\hline $\begin{array}{l}\text { Haynes, B. (2010) International Small Business Growth: } \\
\text { A Process Perspective, 29:2, pp. 87-106 }\end{array}$ & $\begin{array}{l}\text { Conceptual and empirical } \\
\text { (in-depth interviews) }\end{array}$ & $\begin{array}{l}\text { Takes a process view of internationalisation as a } \\
\text { means of achieving SME growth. }\end{array}$ \\
\hline $\begin{array}{l}\text { Ryan, P., Moroney, M., Geoghegan, W., and Cunningham, } \\
\text { J. (2007) A Framework for a Strategic Repositioning Strategy: } \\
\text { A Case Study of Bulmers Original Cider, 28:1, pp. 81-1020 }\end{array}$ & $\begin{array}{l}\text { Case study; in-depth, } \\
\text { open interviews with } \\
\text { triangulation. }\end{array}$ & $\begin{array}{l}\text { Views strategic repositioning as a conscious } \\
\text { adaptation to a changing environment. }\end{array}$ \\
\hline $\begin{array}{l}\text { Talbot, P. A. (2003) Corporate Generals: The Military Metaphor } \\
\text { of Strategy. } 24: 2 \text {, pp. } 1-10\end{array}$ & Conceptual & $\begin{array}{l}\text { Takes a Metaphorical View of Military Strategy } \\
\text { as a lens through which to examine strategic } \\
\text { initiatives }\end{array}$ \\
\hline $\begin{array}{l}\text { Mc Carthy, B. (2003) The Impact of the Entrepreneur's } \\
\text { Personality on the Strategy-Formation and Planning Process } \\
\text { in SMEs. } 24: 1 \text { pp. } 154-172\end{array}$ & $\begin{array}{l}\text { Conceptual -/empirical } 33 \\
\text { semi-structured interviews }\end{array}$ & $\begin{array}{l}\text { Examines the relationship between the } \\
\text { entrepreneur's character and the development } \\
\text { of strategy }\end{array}$ \\
\hline $\begin{array}{l}\text { Griggs, H. E. (2002) Strategic Planning System Characteristics } \\
\text { and Organisational Effectiveness in Australian Small-Scale Firms. } \\
23: 1, \text { pp. } 23-51\end{array}$ & $\begin{array}{l}\text { Empirical. Single industry } \\
\text { study - questionnaire }\end{array}$ & $\begin{array}{l}\text { Focuses on the correlation between strategic } \\
\text { planning and organisational effectiveness in } \\
\text { Australian small-scale business }\end{array}$ \\
\hline $\begin{array}{l}\text { Gibbons, P. T and O'Brien, M. (2001) Socialisation and Chief } \\
\text { Executive Commitment to the Status Quo 22:2, pp. 143-170 }\end{array}$ & $\begin{array}{l}\text { Replication study } \\
\text { questionnaire }\end{array}$ & $\begin{array}{l}\text { Examines the commitment of CEOs to the } \\
\text { status quo }\end{array}$ \\
\hline $\begin{array}{l}\text { Lawton, T. C and Michaels, K.P. (2001) Advancing to the Virtual } \\
\text { Value Chain: Learning from The Dell Model. 22:1, pp. 91-112 }\end{array}$ & Conceptual/case study & $\begin{array}{l}\text { Relating Corporate Structure to Strategy in the } \\
\text { Internet Age }\end{array}$ \\
\hline $\begin{array}{l}\text { McCarthy, B and Leavy, B. (2000), Phases in the Strategy } \\
\text { Formation Process: An Exploratory Study of Irish SMEs, 21:2, } \\
\text { pp. 55-80 }\end{array}$ & $\begin{array}{l}\text { Longitudinal, case-based } \\
\text { inductive approach }\end{array}$ & $\begin{array}{l}\text { Analyses the formation and evolution of } \\
\text { strategic processes in the small- and medium- } \\
\text { sized enterprises }\end{array}$ \\
\hline $\begin{array}{l}\text { Moroney, M. (2000) Strategy Evaluation: Towards an Updated } \\
\text { Paradigm, 21(1), pp. 103-129 }\end{array}$ & Case studies & $\begin{array}{l}\text { Strategy evaluation viewed an integral part of } \\
\text { the strategy process }\end{array}$ \\
\hline $\begin{array}{l}\text { O'Toole, T and Harrington, D, (1998) Tracing the evolution of } \\
\text { quality management: Lessons from the development of strategic } \\
\text { management. Vol. 19(2) pp. 139-152 }\end{array}$ & Literature review & $\begin{array}{l}\text { Parallels the development of the quality } \\
\text { management concept with that of strategic } \\
\text { management }\end{array}$ \\
\hline $\begin{array}{l}\text { Martell, K., Gupta, A., and Carroll S. J. (1996) Human Resource } \\
\text { Management Practices, Business Strategies and Financial } \\
\text { Performance: A Test of Strategy Implementation Theory. 17(1) } \\
\text { pp. 18-35 }\end{array}$ & Moderated regression & $\begin{array}{l}\text { Examine the TMT HRM/performance linkage } \\
\text { universally and within specific strategy settings. }\end{array}$ \\
\hline $\begin{array}{l}\text { Smith, K. A. and Kofron, E. A. (1996) Toward a Research Agenda } \\
\text { on Top Management Teams and Strategy Implementation. 17:1, } \\
\text { pp. 135-149 }\end{array}$ & $\begin{array}{l}\text { Develops research } \\
\text { questions }\end{array}$ & $\begin{array}{l}\text { Focus on the relationship between } \\
\text { top management teams and strategy } \\
\text { implementation and performance }\end{array}$ \\
\hline $\begin{array}{l}\text { Gibbons, P. T; Chung, L. H. (1995) 16:1 Defining Uncertainty: } \\
\text { The Implications for Strategic Management. 16(1) pp. 25-50. }\end{array}$ & $\begin{array}{l}\text { Literature review; theory } \\
\text { Development false }\end{array}$ & $\begin{array}{l}\text { Provides a systematic and comprehensive } \\
\text { conceptualisation of uncertainty }\end{array}$ \\
\hline Tiernan, S. (1993) Innovations in Organisational Structure. 14:1 & Case study false & Examines changes in organisational structure. \\
\hline
\end{tabular}

\section{Theme 2, Industry and Firm Effects}

None of the IJM papers in our sample directly considers industry and firm effects 


\section{Theme 3, Co-operative relationships}

\begin{tabular}{|c|c|c|}
\hline Author & $\begin{array}{l}\text { Methodology/ } \\
\text { Approach }\end{array}$ & Position on Strategy \\
\hline $\begin{array}{l}\text { Gomes, E., Donnelly, T., Morris, D., and Collis, C. (2007), } \\
\text { Improving Merger Process Management Skills over Time: A } \\
\text { Comparison of Acquisition Processes of Jaguar and of Land } \\
\text { Rover by Ford, 28:1, pp. 31-40 }\end{array}$ & $\begin{array}{l}\text { Case study/semi- } \\
\text { structured interviews }\end{array}$ & $\begin{array}{l}\text { Corporate strategy: Investigates the critical } \\
\text { factors underpinning mergers and acquisitions. }\end{array}$ \\
\hline $\begin{array}{l}\text { O'Byrne, D., Angwin, D. (2003) Changing Sub-Unit Boundaries } \\
\text { During a Merger. Vol 24:1 pp. 194-214 }\end{array}$ & $\begin{array}{l}\text { Case study/semi- } \\
\text { structured interviews }\end{array}$ & $\begin{array}{l}\text { Corporate Strategy: Examines what happens to } \\
\text { organisational boundaries as firms embark on } \\
\text { integrating an acquisition. }\end{array}$ \\
\hline $\begin{array}{l}\text { Coughlan, P, Coughlan, D, Brennan, L., Lombard, F., McNicols, } \\
\text { T., Nolan, R. (2002) Collaboration in High Technology } \\
\text { Companies in Ireland: Three Case Studies. 23:1 pp. 19-29 }\end{array}$ & Case studies & $\begin{array}{l}\text { Collaborative relationships between firms and } \\
\text { their suppliers. }\end{array}$ \\
\hline $\begin{array}{l}\text { Boyle, E. (1993) Value-adding Partnerships as alternatives to } \\
\text { Vertical Integration: An exploratory discussion by reference to } \\
\text { some Northern Ireland examples. } 14: 2\end{array}$ & false Case studies & $\begin{array}{l}\text { Choice between competing in the market place } \\
\text { or trough vertical integration. }\end{array}$ \\
\hline
\end{tabular}

\section{Theme 4, Resource-based view}

\begin{tabular}{|c|c|c|}
\hline Author & $\begin{array}{l}\text { Methodology/ } \\
\text { Approach }\end{array}$ & Position on Strategy \\
\hline $\begin{array}{l}\text { López, V. A., and Iglesias, S. (2010), A Reputational-Performance } \\
\text { Framework in an SME Context: Some Empirical Evidence from } \\
\text { Spain., 29:2 pp. 35-66 }\end{array}$ & $\begin{array}{l}\text { Conceptual/empirical } \\
\text { (structured equation } \\
\text { modelling) }\end{array}$ & $\begin{array}{l}\text { Analyses the role played by intangible } \\
\text { resources as sources of competitive advantage }\end{array}$ \\
\hline $\begin{array}{l}\text { López, V. (2006), An Alternative Methodology for Testing a } \\
\text { Resource-Based View Linking Intangible Resources and Long- } \\
\text { Term Performance, } 27: 2 \text {, pp. 49-66 }\end{array}$ & $\begin{array}{l}\text { Empirical. Uses main } \\
\text { component analysis } \\
\text { together with hierarchical } \\
\text { segmentation modelling. }\end{array}$ & Intangible resources impact firm performance \\
\hline $\begin{array}{l}\text { Kenny, B and Reedy, E. (2006), The Impact of Organisational } \\
\text { culture Factors on Innovation Levels in SMEs: An Empirical } \\
\text { Investigation. } 27: 2 \text {, pp. 119-142 }\end{array}$ & Empirical - Questionnaire & $\begin{array}{l}\text { Cultural factors contribute to the stimulation of } \\
\text { innovation and creativity within organisations }\end{array}$ \\
\hline $\begin{array}{l}\text { Weisingera, J. Y, and Black, J. A. (2006) Strategic Resources and } \\
\text { Social Capital. 27:1, pp. 145-170 }\end{array}$ & Conceptual/case study & $\begin{array}{l}\text { The study considers how social capital is being } \\
\text { used in the development of strategic resources } \\
\text { in the achievement of strategic goals? }\end{array}$ \\
\hline $\begin{array}{l}\text { Frawley, T, and Fahy, J. (2006). Revisiting the First-Mover } \\
\text { Advantage: A Resource Based Perspective. 27:1, pp. 273-295 }\end{array}$ & Conceptual & $\begin{array}{l}\text { Seeks to integrate the resource-based view with } \\
\text { the literature on first-mover advantage. }\end{array}$ \\
\hline $\begin{array}{l}\text { López, V. A. (2003) Intangible Resources as Drivers of } \\
\text { Performance: Evidence from a Spanish Study of Manufacturing } \\
\text { Firms. 24:2, pp. 125-134 }\end{array}$ & $\begin{array}{l}\text { Conceptual/empirical } \\
\text { factor analysis and } \\
\text { regression }\end{array}$ & $\begin{array}{l}\text { Expounds a conceptual framework which, } \\
\text { following the resource-based view (RBV) of the } \\
\text { firm, enables us to know the significance of } \\
\text { a group of intangible resources in relation to } \\
\text { business performance. }\end{array}$ \\
\hline
\end{tabular}

\section{Theme 5, Knowledge-Based View}

\begin{tabular}{lll}
\hline Author & $\begin{array}{l}\text { Methodology/ } \\
\text { Approach }\end{array}$ & Position on Strategy \\
\hline \hline $\begin{array}{l}\text { Higgins, D. (2006) Theoretical Assumptions of Knowledge } \\
\text { Creation. 27:2 pp. 189-213 }\end{array}$ & $\begin{array}{l}\text { Conceptual } \\
\text { The creation and utilisation of knowledge is } \\
\text { of major importance to the success of firms, } \\
\text { especially knowledge-intensive firms(KIFs). }\end{array}$ & $\begin{array}{l}\text { Leadership characteristics impact the learning } \\
\text { capacity of the organisation. }\end{array}$ \\
$\begin{array}{lll}\text { J., and West, M. (2005) CEO Leadership, Top Team Trust and the } \\
\text { Combination and Exchange of Information., 26:1, pp. 22-40 }\end{array}$ & $\begin{array}{l}\text { Conceptual/empirical } \\
- \text { survey questionnaire, } \\
\text { semi-structured interviews; } \\
\text { factor analysis, regression }\end{array}$ & $\begin{array}{l}\text { Theoretical/bibliometric } \\
\text { Ryan, S., and Hurley, J. (2004) Have Total Quality Management, } \\
\text { Business Process Re-engineering and the Learning Organisation } \\
\text { been Replaced by Knowledge Management. 25:1,pp. 41-55 }\end{array}$ \\
$\begin{array}{l}\text { TQM, BPR, LO and KM wherein KM is seen to } \\
\text { supersede the other theories. }\end{array}$
\end{tabular}




\section{Theme 6, Dynamic capabilities}

\begin{tabular}{|c|c|c|}
\hline Author & $\begin{array}{l}\text { Methodology/ } \\
\text { Approach }\end{array}$ & Position on Strategy \\
\hline $\begin{array}{l}\text { Walsh, M., Lynch, P and Harrington, D. (2011) } \\
\text { A Capability-Based Framework for Tourism } \\
\text { Innovativeness } \\
\text { Vol. } 31 \text { Issue 1, pp. 21-41.21p. }\end{array}$ & Conceptual & $\begin{array}{l}\text { Uses RBV and Dynamic capability to explore } \\
\text { reconfiguration of pools of resources. }\end{array}$ \\
\hline $\begin{array}{l}\text { Higgs, M. (2006) What Makes for Top Team Success? A Study to } \\
\text { Identify Factors Associated with Successful Performance of Top } \\
\text { Management Teams. } 27: 2 \text { pp. } 161-188\end{array}$ & Conceptual and empirical. & $\begin{array}{l}\text { Examines the relationship between top } \\
\text { management team dynamics and performance. }\end{array}$ \\
\hline $\begin{array}{l}\text { Lawton, T.C. (2003) Managing Proactively in Turbulent Times: } \\
\text { Insights from the Low-Fare Airline Business. 24:1, pp. 173-193. }\end{array}$ & $\begin{array}{l}\text { Case study/industry } \\
\text { analysis }\end{array}$ & Examines strategy in a turbulent environment. \\
\hline $\begin{array}{l}\text { O'Driscoll, A., Carson, D., and Gilmore, A. (2001) The } \\
\text { Competence Trap: Exploring Issues in Winning and Sustaining } \\
\text { Core Competence. 22:1, pp. 73-90 }\end{array}$ & Case studies & $\begin{array}{l}\text { Examines factors in winning and sustaining core } \\
\text { competencies. }\end{array}$ \\
\hline $\begin{array}{l}\text { Smith, K. G; Smith, K. A., Olian J.D; and Sims, H. P. (1996), Top } \\
\text { Management Team Demography and Process: The Role of Social } \\
\text { Integration and Communication. 17:1 pp. 36-69. }\end{array}$ & $\begin{array}{l}\text { Hierarchical regression of } \\
\text { three alternative models }\end{array}$ & $\begin{array}{l}\text { Top management team factors impact firm } \\
\text { performance through demographics, process } \\
\text { and their interaction. }\end{array}$ \\
\hline
\end{tabular}

\section{Notes:}

Haynes, B. (2010) International Small Business Growth: A Process Perspective., 29:2, pp. 87-106, categorised under strategy and structure above also exhibits elements of cooperative relationships and capabilities.

Gomes, E., Donnelly, T., Morris, D., and Collis, C. (2007), Improving Merger Process Management Skills over Time: A Comparison of Acquisition Processes of Jaguar and of Land Rover by Ford, 28:1, pp. 31-40, categorised under cooperative relationships above also exhibits significant elements of organisational learning/knowledge management. 